\title{
S28 - Consecuencias del divorcio en niños y adolescentes en San Pedro Sula, Honduras
}

\author{
Pedronel González Rodríguez \\ Escuela de Ciencias Psicológicas, Universidad de San Carlos de Guatemala.
}

*Autor al que se dirige la correspondencia: ppedronel@hotmail.com

\section{Resumen}

a presente investigación cuantitativa con enfoque descriptivo, detalla las consecuencias del divorcio en niños
y adolescentes desde la perspectiva de los adultos, en la ciudad de San Pedro Sula, Cortes, Honduras. La in-
vestigación es parte de una encuesta respondida por 423 personas que residen en San Pedro Sula, quienes conocían
el caso de un niño o joven cuyos padres se habían divorciado. Los encuestados refirieron que las consecuencias
observadas en los niños o los adolescentes después del divorcio se manifestaron a nivel conductual, afectivo/
sentimental, somático, interpersonal, cognitivo, nuevo estilo de vida, académico, económico, uso de servicios de
salud mental y desarrollo de síndromes post divorcio.

Palabras claves: Conductual, afectivo, somático, interpersonal

\begin{abstract}
$\mathrm{T}$

his quantitative research with a descriptive approach, details the consequences of divorce on children and ad-

olescents from an adult perspective, in the city of San Pedro Sula, Cortes, Honduras. The research is based on a survey answered by 423 people living in San Pedro Sula, who knew the case of a child or young person whose parents had divorced. Interviewed referred that the effects observed in children or adolescents after divorce were expressed at behavioral level, affective / emotional, somatic, interpersonal, cognitive, new lifestyle, academic, economic, use of mental health services and development syndromes post-divorce.
\end{abstract}

Keywords: Behavioral, emotional, somatic, interpersonal 